\title{
Recent Advances of Anaerobic ammonium oxidation Technology
}

\author{
Jiabin Wang ${ }^{1,2, a^{*}}$, Dong Zhang ${ }^{2, b}$, Xing Li ${ }^{1, c}$, Lingli Zhu ${ }^{2, d}$, Kang Xie ${ }^{2, e}$
}

${ }^{1}$ The College of Architecture and Civil Engineering, Beijing University of Technology, Beijing $100022,{ }^{2}$ School of Architectural and Civil Engineering, University of Jinan, Jinan 250022, PR China

acea_wangjb@ujn.edu.cn, bzdmxcz1@sina.com, 'lixing@vip.163.com, 'azazhulingli@sina.com,

ecea_xiek@ujn.edu.cn

* Corresponding Author

e-Mail:zdmxcz1@sina.com

Keywords: Anaerobic ammonium oxidation(anammox); Recent Advances; Environmental Factors; Magnetic Field.

Abstract. Anammox process has been recently recognized as a promising technology for nitrogenous contaminants removal. of the anammox attracted more attention because of its lower sludge production and cost of without adding organic carbon source and aeration, In this study, the development of anammox, application status of anammox technology was reviewed. The limitations, applications and prospect of anammox technology was also summarized.

\section{Development of Anammox}

Discovery of Anammox. In 1977, Austrian theoretical chemist Broda predicted the presence of ammonia oxidation in the presence of nitrate or nitrite under anaerobic conditions in nature ${ }^{[1]}$. Until 1990s, it was confirmed in a pilot plant treating wastewater at Delft University of Technology. Mulder found the simultaneous loss phenomenon of ammonia and nitrate in a three-stage biological treatment systems, and proved that the ammonia and nitrate convert simulataneously and produce nitrogen gas. The reaction process is called anammox ${ }^{[2]}$.

Reaction Mechanism of Anammox. Anaerobic ammonia oxidation bacteria (AAOB) use ammonium as electron donor, with nitrite as electron acceptor to produce nitrogen gas under anaerobic conditions. The stoichiometric relationship of anammox ${ }^{[3]}$ was shown in equation 1 . The substrate required for the reaction are ammonium and nitrite, and the alkalinity was generated. The reaction can be divided into two parts. The first part is the energy production process, as shown in equation 2. The second part is biomass generation process, as shown in equation 3.

$$
\begin{aligned}
& \mathrm{NH}_{4}^{+}+1.32 \mathrm{NO}_{2}^{-}+0.066 \mathrm{HCO}_{3}^{-}+0.13 \mathrm{H}^{+} \rightarrow 1.02 \mathrm{~N}_{2}+0.26 \mathrm{NO}_{3}^{-}+0.066 \mathrm{CH}_{2} \mathrm{O}_{0.5} \mathrm{~N}_{0.15}+2.03 \mathrm{H}_{2} \mathrm{O} . \\
& \mathrm{NH}_{4}{ }^{+}+\mathrm{NO}_{2}^{-} \rightarrow \mathrm{N}_{2}+2 \mathrm{H}_{2} \mathrm{O} \quad \triangle \mathrm{G}=-357 \mathrm{KJ} / \mathrm{mol} . \\
& 0.26 \mathrm{NO}_{2}^{-}+0.066 \mathrm{HCO}_{3}^{-} \rightarrow 0.26 \mathrm{NO}_{3}^{-}+0.066 \mathrm{CH}_{2} \mathrm{O}_{0.5} \mathrm{~N}_{0.15} .
\end{aligned}
$$

AAOB and Biological Characteristics. At present, 9 species of 5 genera of AAOB were isolated and identified. AAOB are gram negative bacteria, budding reproduction. Cell was divided into three parts: anammoxosome, riboplasm, paryphoplasm. The anammox process occurs in the anammoxosome, which accounts for $50 \%-80 \%$ of the cell volume ${ }^{[4]}$. AAOB have a long generation time (about 11 days), in a short period of time, anammox reactor difficult to enrich the larger concentrations of bacteria. According to the reports in the literature, the anammox activity showed strong correlation with anammox abundance. The first physical anammox reactor was launched at Netherlands for two years. 


\section{Anammox Biological Nitrogen Removal Technologies}

At present, anammox technology is relatively mature in the laboratory stage, and successfully applied to the practical sewage treatment. the realization of the technology mainly are two ways: 1) one section type: in a single stage reactor, it is a biological membrane method and fully mixed suspension culture mode; 2) Two section type: first paragraph is sharon segment, 50 - 60\% of the ammonia is oxidized to nitrite, second paragraph is anammox segment: the rest of the ammonia nitrogen and the nitrate in anammox reaction generated nitrogen gas.

Anammox technology has been widely used in low carbon and nitrogen ratio sewage treatment, in the garbage infiltration filtrate, aquaculture sewage, municipal sludge liquor, monosodium glutamate sewage, have achieved excellent results. Typical anammox projects are listed in table 1.

Table1. Examples of typical anammox projects

\begin{tabular}{|c|c|c|c|c|c|}
\hline $\begin{array}{c}\text { Technology } \\
\text { type }\end{array}$ & place & Processing object & $\begin{array}{c}\text { Reactor } \\
\text { volume } \\
\left(\mathrm{m}^{3}\right)\end{array}$ & $\begin{array}{l}\text { Nitrogen remove } \\
\left(\mathrm{KgN} \mathrm{m}^{-3} \mathrm{~d}^{-1}\right)\end{array}$ & $\begin{array}{r}\text { start } \\
\text { time } \\
\text { (d) }\end{array}$ \\
\hline Canon & China & Monosodium glutamate sewage & 6700 & 1.67 & 30 \\
\hline Anammox & China & Yeast production sewage & 500 & 2 & - \\
\hline Canon & China & Fermentation sewage & 500 & 2 & - \\
\hline Anammox & China & Pharmaceutical sewage & 4300 & 1.42 & - \\
\hline $\begin{array}{l}\text { Sharon+ } \\
\text { Anammox }\end{array}$ & Netherland & Municipal sludge liquor & 1500 & 9.5 & 1260 \\
\hline $\begin{array}{l}\text { Sharon+ } \\
\text { Anammox }\end{array}$ & Japan & Semiconductor waste liquid & 1500 & 1.9 & 60 \\
\hline Canon & witzerland & Municipal sludge liquor & 160 & 1.9 & 90 \\
\hline Canon & Netherland & Potato processing waste liquid & 600 & 1.3 & 180 \\
\hline
\end{tabular}

The applications of anammox biological nitrogen removal technologies in low carbon and nitrogen ratio sewage treatment, point to the strong potential for its use in more field, despite some remaining challenges. These main challenges are achieving nitrite accumulation, and retaining anammox bacteria .

\section{Study on the Dynamic process of Anammox}

AAOB were enriched slowly, sensitive to the external environment. Start-up time of anammox process is long, the stringent requirements of the operation parameter limits the applications of process in a wide range of sewage treatment. According to the affecting factors of process, researchers have done a lot of research, including the environment,nutrition, sludge, magnetic field, providing effective parameters on anammox reactor.

\section{Environmental Factors.}

PH. The influence of PH on anammox was embodied in two aspects. On the one hand, it brings directly impact, that is to say, the growth needs of $\mathrm{AAOB}$, it is optimum to grow in neutral and alkaline environment. Zheng ${ }^{[5]}$ found that the optimal PH of anammox is in the vicinity of 7.5 to 8.0. When the PH value from 6 to 7.5, the reaction rate was increased; However, when the PH value up to 9, the anammox reaction was declined constantly. On the other hand, it brings indirect impact, namely, it affects the proportion of reaction substrates in the water.Yang Yang ${ }^{[6]}$ show that anammox optimum $\mathrm{PH}$ value is between 7.5 to 8.3 . When the $\mathrm{PH}$ value equal to 8.3 , the activity of anammox sludge is largest.

Temperature. The activation energy (Ea) of anammox is as high as $93 \sim 94 \mathrm{~kJ} / \mathrm{mol}$, Activation energy is larger.Increasing temperature is helpful to accelerate reaction. Anammox generally takes 
place at temperatures from 6 to $43^{\circ} \mathrm{C}$; The anammox reaction is more sensitive to temperature changes, and $31^{\circ} \mathrm{C}$ should be the best temperature of anammox reaction. When the temperature of the reactor is from 31 to $17{ }^{\circ} \mathrm{C}$, the reactor rate drops rapidly ${ }^{[7]}$. However, when it is at a lower temperature, AAOB is still active. Therefore, in the case of low nitrogen load and low temperature, there are a little effects on anammox nitrogen removal technologies.

\section{Nutritional Formula}

Substrate. AAOB habitat requires the simultaneous presence of ammonium and nitrite. When nitrite was accumulated in a certain degree, it can inhibit anammox process. The experiment of AAOB exposing to nitrite show that, when the concentrations of nitrite more than $100 \mathrm{mg} \mathrm{N} / \mathrm{L}$, anammox process was completely inhibit. When the concentrations of ammonium above $122 \mathrm{mg} / \mathrm{L}$, activity of AAOB was restrained ${ }^{[8]}$. A large number of studies have shown that a high concentrations of ammonium to the inhibition of anammox is reversible. Activity of anammox can be restore quickly by reducing the concentrations of ammonium in the water. By the in-depth experiment, it can be the index that the substrate inhibition is relieved and reactor recovers to operating stability at effluent concentrations of ammonium less than $10 \mathrm{mg} / \mathrm{L}^{[9]}$. Substrate inhibition mechanism of nitrite is that key enzyme activity of anammox was inhibited.It is generally believed that the inhibitory effect of ammonia on AAOB mainly from FA instead of ammonia. The concentrations of FA in solution from 57 to $187 \mathrm{mg} / \mathrm{l}$ will inhibit the activity of AAOB.

Organic matter. Anammox community is chemoautotrophic microorganisms with $\mathrm{CO}_{2}$ as the main carbon source. The influence of organic matter on anammox mainly are two points of view: one is the coexistence of AAOB and denitrifying bacteria in low concentrations of organic matter, when high concentrations of organic matter, anammox was inhibited. Second, diversity of metabolic pathway of anammox, in the presence of organic matter, AAOB compete organic matter with denitrifying bacteria. Anammox reaction still accounts for a dominant position when there have the organic matter ${ }^{[10]}$. Anammox was limited at concentrations of organic matter higher than $290 \mathrm{mg}$ $/ \mathrm{L}^{[11]}$. AAOB have a competitive advantage of propionic acid compared with denitrifying bacteria. In fact, organic carbon, inorganic carbon coexists in real wastewater. Thus, it is necessary to findout what is the key factor affecting the nitrogen removal performance of this mixed anammox-based system.

Metal Ions. Trace heavy metal is a nutrient for microbial life activity, and it is also an activator or active base of enzyme. By means of transmission electron microscope and energy spectrum analysis, the iron element was found in the body of AAOB. $\mathrm{Li}^{[12]}$ cultivate the anammox reactor containing $\mathrm{Fe}^{2+}$ for 71 cycles, nitrogen removal efficiency increased from $0.28 \mathrm{~kg} /(\mathrm{m} 3 \cdot \mathrm{d})$ to $0.65 \mathrm{~kg} /(\mathrm{m} 3 \cdot \mathrm{d})$. Copper, zinc and other heavy metal ions will have a certain impact on AAOB.The influence of $\mathrm{Cu}^{2+}$ and $\mathrm{Zn}^{2+}$ on anammox sludge can be divided into 3 stages: stimulation, stabilization and inhibition. In the long-term cultivation process, in order to avoid the inhibition of the activity of anammox sludge, the influent concentrations of $\mathrm{Cu}^{2+}$ and $\mathrm{Zn}^{2+}$ should be lower than $4 \mathrm{mg} / \mathrm{L}$. The effects of heavy metal on biological nitrogen removal system are not the same.

\section{Sluge}

In the starting process of the reactor,starting inoculation sludge is mainly divided into: anammox sludge, activated sludge, sediments. Tal ${ }^{[13]}$ uses nitrification sludge and denitrification sludge as inoculated sludge to start reactor. The results shows that the anammox activity was higher in denitrifying sludge. A series of research results showed that the activity of AAOB in the sludge affect the reactor start-up time directly. Forming granules is a feasible way to improve biomass retention. Anammox granular sludge is a complex of anammox bacteria and several kinds of nitrogen removal bacteria. The removal rate of $2090 \mathrm{mg} /(\mathrm{L} \cdot \mathrm{d})$ was obtained when the anaerobic granular sludge was used as inoculated sludge. At the same time, it can be concluded that granular sludge could bear higher substrate concentration. Particle size has an important influence on the activity of anammox granular sludge. Studies have indicated that the process of anammox mainly occurs in the range of $1 \mathrm{~mm}$ thickness on the surface of granular sludge ${ }^{[14]}$. The pores in the granular sludge can help to improving the efficiency of mass transfer. 


\section{Magnetic Field}

Magnetic field was useful and reliable for fast start-up of anammox process since it was proved as a simple and convenient approach to enhance anammox activity. The reactor with magnetic field of 60 $\mathrm{mt}$, a significant $30 \%$ increase in maximum nitrogen removal rate and an approximate 1/4 saving in cultivation time were achieved $^{[15]}$. The maximum removal rate of ammonia nitrogen in the magnetic field strength of 60MT, ammonia nitrogen removal rate reached 93\%. Magnetically embedded anammox pellets were successfully prepared.Under the action of magnetic field, the biological treatment system has a good application prospect.

\section{Conclusion and Prospect}

This studied reviewed recent advances of anammox in sewage treatment. According to the studies of anammox technology, the doubling time of AAOB is long, the cell yield is low. Therefore, good retention of $\mathrm{AAOB}$ is the premise of achieving sewage treatment via anammox. The optimum operation conditions and nutritional formula and suitable enrichment culture can shorten the starting time of the anammox technology. The anammox technology expand the wastewater treatment and exhibit a good performance of pollutions emission reduction and energy saving.

\section{Acknowledgements}

This study was supported by Shangdong Provincial Natural Science Foundation, China (ZR2013EEQ007), and was partly supported by National Natural Science Foundation of China (51278225), Science and technology development projects of Shandong province (2013GSF11704), Shangdong Provincial Natural Science Foundation, China (ZR2015EM021).

\section{References}

[1] Broda E: Zallg Milkrobiol Vol. 17(1977), p. 491- 493.

[2] Strous M, Heijnen J J, Kuenen J G: Appl Microbiol Biotechnol Vol. 50(1998), p. 589-596.

[3] Mulder A, Vande Graaf A, Robertson L A: FEMS Mierobiol Ecol Vol. 16(1995), p. 177-183.

[4] van Niftrik L, Geerts W J C, van Donselaar E G: Journal of bacteriology Vol. 2(2008), p. 708-717.

[5] Ping Zheng,et al: Chinese Journal of Biotechnology Vol. 2(2001), p. 193-198.In Chinese.

[6] Yang Yang,et al : Chinese Journal of Environmental Engineering Vol. 4(2006), p. 691-695.In Chinese.

[7] Junqin Yao,et al : Chinese Journal of Environmental EngineeringVol. 10(2013), p. 3993-3996.In Chinese.

[8] Yong chen,et al: China Water \& Wastewater Vol. 17(2006), p. 74-76.In Chinese.

[9] Chongjian Tang,et al: Journal of Central South University of Technology Vol. 1(2010), p. 79-84.In Chinese.

[10] Chenbing Cao,et al: China Environmental Science Vol. 12(2013), p. 2164-2169.In Chinese.

[11] Molinuevo B, Cruz Garcia M: Bioresource Technology Vol. 7(2013), p. 2171-2175.

[12] Xiang Li,et al: Chinese Journal of Environmental Engineering Vol. 34(2014), p.924-929.In Chinese.

[13] Tal Y, Watts J E M, Schreier H J: Applied and Environmental Microbiology Vol. 4(2006), p.2896-2904.

[14] An P, Xu X C, Yang F L: Biotechnology and Bioprocess Engineering Vol. 3(2013), p.446-454. 
[15] Liu S, Yang F, Meng F: Journal of Biotechnology Vol. 3(2008), p.96-102. 